\title{
MISKONSEPSI SISWA BIOLOGI TENTANG MATERI SISTEM RESPIRASI PADA SMA NEGERI SE-KABUPATEN LABUHANBATU
}

\author{
Nurhakima Ritonga* ${ }^{1}$, Halimah Sakdiah Boru Gultom ${ }^{2}$, Novi Fitriandika Sari ${ }^{3}$ \\ ${ }^{123}$ Program Studi Pendidikan Biologi, STKIP Labuhanbatu \\ JL. Sisingamangaraja No. 126 A Km. 3,5 Aek Tapa, Rantauprapat, North Sumatera, Indonesia \\ Email: nurhakimaritonga00@gmail.com
}

\begin{abstract}
ABSTRAK
Penelitian ini bertujuan untuk menganalisis miskonsepsi siswa tentang materi sistem respirasi pada SMA Negeri se-Kabupaten Labuhanbatu serta untuk mengidentifikasi ada tidaknya miskonsepsi. Penelitian ini dilaksanakan di SMA Negeri se-Kabupaten Labuhanbatu. Populasi dalam penelitian ini adalah seluruh siswa SMA Negeri se-Kabupaten Labuhanbatu, dengan menggunakan test diagnostik. Hasil penelitian menunjukkan bahwa miskonsepsi terjadi pada siswa. Hasil analisis menunjukkan bahwa miskonsepsi pada siswa terhadap materi respirasi, pada konsep respirasi pada yaitu konsep tentang alat pernapasan manusia ( $\mathrm{K} 2$ ), konsep tentang pertukaran gas (K 4), konsep tentang kelainan dan penyakit pada sistem pernafasan manusia (K 5) dan konsep tentang sistem pernapasan hewan invertebrata (serangga) (K 6). Berdasarkan temuan dapat di analisis miskonsepsi pada siswa terhadap materi respirasi teridentifikasi mengalami miskonsepsi pada keseluruhan konsep dan perlu meningkatkan pengetahuan konsep guru melalui pelatihan-pelatihan agar guru dapat membantu siswa dalam memahami konsep sehingga dapat menghindari terjadinya miskonsepsi.
\end{abstract}

Kata Kunci : Miskonsepsi, Respirasi, Siswa Biologi

ABSTRACT

This study aims to analyze student misconception about the respiratory system material in SMA Negeri as Labuhanbatu District and to identify whether there is misconception. This research was conducted in SMA Negeri as Labuhanbatu Regency. The population in this study is all students of SMA Negeri in Labuhanbatu District, by using diagnostic test. The results showed that misconception occurred in students. The results of the analysis to show that the misconception of the students on the respiratory material, on the concept of respiration in the concept of human respiratory equipment (K2), the concept of gas exchange (K4), the concept of abnormalities and diseases of the human respiratory system (K 5) concept of the invertebrate animal (insect) (K 6) respiratory system. Based on the findings can be analyzed misconceptions on the students of the respiratory material identified misconception on the whole concept and need to improve the concept of teacher knowledge through training so that teachers can help students in understanding the concept so as to avoid the occurrence of misconception.

Keywords: Misconception, Respiration, Biology's Student

\section{PENDAHULUAN}

Miskonsepsi dapat menjadi penghalang dalam memahami materi-materi biologi. Banyak konsep-konsep dalam biologi saling berhubungan dan merupakan kunci untuk memahami konsep lain, sehingga miskonsepsi pada satu konsep mengakibatkan miskonsepsi pada yang lain (Tekkaya, 2002). Sebagai contoh, tanpa pemahaman sistem peredaran darah, maka konsep mengenai sistem respirasi, sistem ekskresi dan sistem kekebalan tubuh akan sulit dipahami. Biasanya miskonsepsi terjadi karena konsepkonsep biologi yang bersifat abstrak dan sulit dipahami oleh guru dan siswa.

Miskonsepsi dapat terjadi di dalam dan di luar sekolah. Guru dan buku dapat menjadi sumber miskonsepsi yang terjadi di sekolah. Menurut penelitian Suryanto (1997) seperti yang dikutip Winahyu (2006), banyak guru yang mengalami miskonsepsi. Hiller seperti dikutip Woolfolk dan McCune-Nicolich dalam Hewindati (2004), menyatakan bahwa terdapat hubungan yang erat antara kualitas penjelasan dan pengetahuan guru dengan pencapaian belajar siswa. Kurangnya pengetahuan guru akan menyebabkan tidak jelasnya penyajian pelajaran yang dapat menimbulkan miskonsepsi. Selanjutnya menurut Suparno (2005), selain pengetahuan yang dimiliki guru ternyata buku pelajaran, serta pengalaman sehari-hari siswa juga merupakan penyebab miskonsepsi. 
Munculnya miskonsepsi yang paling banyak adalah bukan selama proses belajar mengajar melainkan sebelum proses belajar mengajar dimulai, yaitu pada konsep awal yang telah dibawa siswa sebelum memasuki proses tersebut atau yang disebut sebagai prakonsepsi (Celement dalam Rohmadi 2009). Prakonsepsi ini bersumber dari pikiran siswa sendiri atas pemahamannya yang masih terbatas pada alam sekitarnya atau sumbersumber lain yang dianggapnya lebih tahu akan tetapi tidak dapat dipertanggungjawabkan kebenarannya. Sumber-sumber prakonsepsi ini misalnya adalah film-film bertemakan teknologi, acara acara fiksi- sains yang tidak tertata rapi, dan bahan-bahan bacaan. Demi melihat ini, untuk mengatasi miskonsepsi yang ada haruslah sumber dari prakonsepsi tersebut digali dan dicermati (Viridi, 2008). Sehingga miskonsepsi dapat menjadi bahaya laten karena menggangu proses belajar akibat adanya logika yang salah saat mempelajari konsep baru yang benar. Disebut bahaya laten karena keberadaanya secara umum tidak terdeteksi saat tidak mendapat tantangan konsep lain (Simanek, 2007). Jika miskonsepsi tidak dapat dihilangkan, miskonsepsi akan berdampak negatif pada kegiatan belajar selanjutnya (Pabucu, 2006).

\section{METODE PENELITIAN}

Teknik pengambilan sampel dalam penelitian ini dilakukan secara sampel wilayah (Area Probability Sample). Sampel wilayah dilakukan apabila ada perbedaan ciri antara wilayah yang satu dengan wilayah yang lain. Sampel wilayah dalam penelitian ini terbagi atas tiga wilayah yaitu kota, transisi dan desa. Yang dimaksud dengan kota adalah Ibukota Kabupaten, dan wilayah daerah transisi merupakan wilayah yang berada diantara wilayah kota dan desa. Berdasarkan sampel wilayah maka jumlah sampel dalam penelitian ini adalah 9 SMA $N$ yang terdiri atas SMA N 2 Rantau Utara dan SMA N 1 Rantau Selatan, SMA N 2 Rantau Selatan (wilayah kota); SMA N 1 Bilah Hulu, SMA N 1 Pangkatan dan SMA $\mathrm{N} 1$ Bilah Hilir (wilayah transisi); SMA N 1 Panai
Hulu, SMA N 1 Panai Tengah dan SMA N 1 Panai Hilir (wilayah desa). Jumlah seluruh siswa kelas XIIPA adalah 895 orang.

Penelitian ini menggunakan metode penelitian deskriptif yaitu kajian yang menyelidiki responden siswa berdasarkan pemahaman konsep dan miskonsepsi terhadap materi sistem respirasi pada SMA Negeri se- Kabupaten Labuhanbatu. Penelitian ini merupakan deskriptif karena hanya menggambarkan apa adanya tentang suatu variabel, gejala atau keadaan karena tidak diperlukan pengontrolan terhadap suatu perlakuan atau tidak dimaksudkan untuk menguji hipotesis.

Langkah-langkah yang harus dilakukan adalah sebagai berikut: (1) melakukan observasi meliputi studi literatur untuk memperoleh data jumlah populasi siswa SMA Negeri se-Kabupaten Labuhanbatu dimana jumlah seluruh siswa biologi dari ke 9 SMA N kelas XI-IPA adalah 895 orang, (2) instrumen yang digunakan untuk mendeteksi miskonsepsi siswa terhadap materi sistem respirasi berupa tes dignostik dua dimensi. Tes diagnostik dalam bentuk pilihan ganda sebanyak 15 butir soal dengan lima kemungkinan jawaban yang diikuti dengan pertanyaan konfirmasi tentang tingkat keyakinan atas jawaban yang dipilih setiap butir soal.

Penyusunan tes diagnostik disusun berdasarkan kisi-kisi penyusunan tes. Kisi-kisi tes diagnostik memuat deskripsi mengenai ruang lingkup, isi, bentuk, serta rincian tes yang akan dikembangkan. Sebelum tes diagnostik digunakan sebagai alat pengumpul data terlebih dahulu dilakukan pendekatan rasional yang digunakan untuk menganalisis kesahihan isi butir-butir tes diagnostik. (3) memberikan instrumen kepada responden kemudian diproses untuk memperoleh data. Pengumpulan data dilakukan dengan mengumpulkan hasil tes pemahaman konsep. Menganalisis data yang diperoleh kemudian membuat kesimpulan berdasarkan data yang dihasilkan. 
Tabel 1. Kemungkinan jawaban, tingkat keyakinan dan bobot skor (Klymkowsky, 2006)

\begin{tabular}{cccc}
\hline No. & Jawaban & Tingkat Keyakinan & Skor Terhadap Jawaban \\
\hline 1. & Benar & Yakin (Y) & +3 \\
2. & Benar & Tidak Yakin (TY) & $+1,5$ \\
3. & Benar & Tidak Tahu (TT) & +1 \\
4. & Salah & Tidak Yakin (TY) & $-0,5$ \\
5. & Salah & Yakin (Y) & -1 \\
\hline
\end{tabular}

Secara lengkap beberapa kombinasi atas jawaban guru yang tertera pada tes diagnostik dan tingkat keyakinan menjawab pertanyaan serta sistem pemberian skornya dapat dilihat pada Tabel 1. Skor tertinggi yang mungkin dicapai seorang sampel adalah +3 dan yang terendah -1 . Apabila siswa menjawab benar dengan tingkat keyakinan "yakin" maka dikategorikan siswa sudah paham konsep. Jika salah dengan tingkat keyakinan "yakin" dan "tidak yakin" maka dikategorikan siswa mengalami miskonsepsi. Dan skor +1 merupakan skor indikator (baseline) untuk mengkategorikan hasil skor yang diperoleh dimana skor yang sama dengan dan lebih dari +1 dikategorikan tidak mengalami miskonsepsi sedang skor dibawah +1 dikategorikan mengalami miskonsepsi. Kemudian dihitung rata-rata skor setiap siswa dari masingmasing sekolah.

Tes diagnostik pada penelitian ini terdiri dari 15 soal pilihan berganda yang berisi tentang konsep-konsep sistem respirasi. Konsep tersebut adalah: (1) Pengertian bernapas dan respirasi berjumlah 1 buah; (2) Alat pernapasan manusia berjumlah soal 3 soal; (3) Proses pernapasan manusia berjumlah 4 buahl;(4) Proses pertukaran gas berjumlah 2 buah; (5) Kelainan dan penyakit pada system pernapasan manusia berjumlah 2 soal; (6) Sistem pernapasan hewan invertebrate (serangga berjumlah 1 buah, (7) Sistem pernapasan hewan vertebrata burung dan ikan) berjumlah 2 buah.

Skor hasil tes pemahaman konsep dari sampel siswa merupakan data kuantitatif. Data ini diproses dengan metode statistik Microsoft Excel untuk mencari rata-rata skor dan standar deviasinya. Hasil yang diperoleh dianalisis secara deskriptif dengan menggunakan Tes Dua Dimensi (Klymkowsky, 2006). Hasil rata-rata skor yang lebih kecil dari +1 dideskripsikan mengalami miskonsepsi oleh sampel siswa. Penentuan materi dan konsep yang dimiskonsepsikan oleh sampel siswa diperoleh dari analisis hasil rata- rata data atau skor awal.

\section{HASIL PENELITIAN}

Deskripsi Data Siswa

Data diperoleh dari skor hasil uji tes pemahaman konsep oleh sampel siswa. Untuk sampel siswa tidak terdapat selisih antara jumlah sampel dalam data dengan jumlah sampel yang tercatat di sekolah. Penjabaran jumlah sampel siswa dari 9 SMA yaitu: RTU II dengan jumlah sampel 119; RTS I dengan jumlah sampel 160; RTS II dengan jumlah sampel 163, BHL dengan jumlah sampel 107; PKT dengan jumlah sampel 78; $\mathrm{BHH}$ dengan jumlah sampel 83, PHL dengan jumlah sampel 85; PTG dengan jumlah sampel 55, $\mathrm{PHH}$ dengan jumlah sampell 45. Keseluruhan responden dari 9 SMA Negeri memiliki persen sampel total $100 \%$.

Siswa responden yang tertera adalah seluruh responden yang menjawab seluruh pertanyaan yang ada pada tes diagnostik dua dimensi. Jadi jumlah siswa sampel yang digunakan dalam memperoleh data miskonsepsi adalah sebanyak 895 siswa yang berasal dari 9 SMA Negeri Se- Kabupaten Labuhanbatu.

\section{Miskonsepsi Siswa Pada Materi Sistem Respirasi}

Hasil analisis miskonsepsi dari rata-rata skor masing-masing materi sistem respirasi keseluruhan siswa yang ada di 9 sekolah diketahui terdapat miskonsepsi pada Konsep 2 (Alat pernapasan manusia), Konsep 4 (konsep tentang pertukaran gas), Konsep 5 (konsep tentang kelainan dan penyakit pada sistem pernafasan manusia) dan Konsep 6 (sistem pernapasan hewan invertebrata (serangga). Perolehan nilai rata-rata dan nilaii standar deviasi (Tabel 2). 
Tabel 2. Skor rata-rata konsep materi sistem respirasi

\begin{tabular}{cccccccc}
\hline Nama Sekolah & \multicolumn{7}{c}{ Nilai Rata-Rata Konsep Sistem Respirasi } \\
\cline { 2 - 8 } & K1 & K2 & K3 & K4 & K5 & K6 & K7 \\
\hline RTU 2 & 2,1 & 0,85 & 1,49 & 1,74 & 1,79 & 0,67 & 1,47 \\
RTS 1 & 2,4 & 0,84 & 1,77 & $-1,0$ & 1,59 & 0,66 & 1,93 \\
RTS 2 & 2,01 & 0.94 & 1,67 & 1,5 & $-1,0$ & 0,97 & 1,75 \\
BHL 1 & 1,9 & 0,69 & 1,55 & $-1,0$ & 1,78 & 0,9 & 1,93 \\
PKT 1 & 1,27 & $-1,0$ & 1,69 & 1,49 & $-1,0$ & 0,97 & 2,13 \\
BHH 1 & 1,83 & 0,84 & 1,78 & $-1,0$ & $-1,0$ & 0,21 & 1,98 \\
PHL 1 & 2,37 & $-1,0$ & 1,5 & $-1,0$ & $-1,0$ & 0,37 & 1,44 \\
PTG 1 & 1,72 & $-1,0$ & 1,37 & $-1,0$ & $-1,0$ & 0,46 & 1,21 \\
PHH 1 & 2,02 & $-1,0$ & 1,28 & $-1,0$ & $-1,0$ & 0,29 & 1,29 \\
\hline Rata-rata & $\mathbf{1 , 9 5}$ & $-\mathbf{0 , 0 8}$ & $\mathbf{1 , 5 6}$ & $-\mathbf{0 , 1 4}$ & $-\mathbf{0 , 0 9}$ & $\mathbf{0 , 6 1}$ & $\mathbf{1 , 6 8}$ \\
\hline SD & $\mathbf{0 , 3 4}$ & $\mathbf{0 , 9 6}$ & $\mathbf{0 , 1 7}$ & $\mathbf{1 , 2 9}$ & $\mathbf{1 , 3 6}$ & $\mathbf{0 , 2 9}$ & $\mathbf{0 , 3 3}$ \\
\hline
\end{tabular}

\section{PEMBAHASAN}

Materi respirasi dimiskonsepsikan oleh keseluruhan siswa SMA Negeri se-Kabupaten Labuhanbatu. Pemetaan miskonsepsi berdasarkan kelompok konsep dari tiap-tiap materi yang dimiskonsepsikan tersebut menunjukkan hasil bahwa keseluruhan siswa mengalami miskonsepsi di 4 konsep respirasi. Adapun konsep-konsep yang dimiskonsepsikan oleh keseluruhan siswa pada materi respirasi adalah konsep tentang alat pernapasan manusia ( $\left.\begin{array}{l}K \\ 2\end{array}\right)$, konsep tentang pertukaran gas ( $K 4$ ), konsep tentang kelainan dan penyakit pada sistem pernafasan manusia ( $K 5$ ) dan konsep tentang sistim pernapasan hewan invertebrata (serangga) (K 6). Hal ini menunjukkan bahwa konsep sistem respirasi memang sulit dipahami. Menurut Amir dan Tamir, dalam Hewindati (2004), konsep respirasi merupakan konsep yang kompleks sehingga miskonsepsi dapat dibawa sebelum proses pembelajaran terjadi. Selain itu konsep ini bersifat abstrak sehingga mengalami kesulitan untuk diajarkan pada semua tingkatan sekolah. Bahkan menurut Afzal (2004) miskonsepsi tentang fisiologi saluran pernapasan masih umum ditemukan pada mahasiswa kedokteran di Pakistan.

\section{KESIMPULAN}

Hasil penelitian miskonsepsi siswa tentang materi respirasi adalah siswa biologi SMA Negeri Se- Kab.Labuhan Batu teridentifikasi mengalami miskonsepsi pada materi respirasi. Analisis miskonsepsi pada siswa terhadap materi respirasi teridentifikasi mengalami miskonsepsi pada keseluruhan konsep materi pada materi respirasi, yang paling sering mengalami miskonsepsi yaitu konsep tentang alat pernapasan manusia, konsep tentang pertukaran gas, konsep tentang kelainan dan penyakit pada sistem pernafasan manusia dan konsep tentang sistim pernapasan hewan invertebrata (serangga).

\section{UCAPAN TERIMA KASIH}

Terima kasih penulis ucapkan kepada kepala sekolah SMA Negeri se-Kabupaten Labuhanbatu sebagai tempat penelitian dan KEMENRISTEK DIKTI yang telah memeberikan dana skema penelitian dosen pemula tahun anggaran 2017.

\section{DAFTAR PUSTAKA}

Afzal, M.N. 2004. Students Misconception in Respiratory Physiology. Journal of Ayub Medical College Abbottabad JAMC, 16 : 14-16.

Hewindati, Y. dan Suryanto, A. 2004. Pemahaman Murid Sekolah Dasar terhadap Konsep IPA Berbasis Biologi: Suatu Diagnosis adanya Miskonsepsi. Jurnal Pendidikan, 5: 61-72.

Klymkowsky, M., Taylor, R., Spindler, S. \& Doxas, R. 2006. Two-Dimensional, Implicit Confidence Tests as a Tool for Recognizing Student Misconceptions. Journal of College Science Teaching.

Pabucu. 2011. Pembelajaran Berbasis Teknologi Informasi dan Komunikasi. Rajawali Pers. Bandung.

Rohmadi, N. 2009. Miskonsepsi Kimia SMA/MA. (http://www.scribd.com /doc/18678424/proposal-tesis- 
Halaman : 042 - 046

Miskonsepsi-Kimia-SMA/MA, diakses tanggal 30 Januari 2010).

Simanek. 2007. Efektifitas Media Pembelajaran Dalam Menunjang Profesionalisme Guru, LPMP Sumatera Utara, Medan.

Suparno, 2005. Metodologi Penelitian Pendidikan. Bumi Aksara. Yogyakarta.

Tekkaya, C., Ozkan, O \&Sungur, S. 2001. Biology Concepts Perceived as Difficult by Turkish High School Students.

Hacettepe Universitesi Egitim Fakultesi Dergisi. Vol. 21: 145-150.

Viridi, S. 2008. Miskonsepsi dalam Fisika. Loka karya Pembina Olimpiade Sains Bidang Fisika Basic Science Center A, Institut Teknologi Bandung, 16-17 Juli 2008.

Winahyu, S. \& Kartini, H. 2006. Konsepsi Siswa dan Guru tentang Konsep-konsep IPA di SD se Kota Malang. 